\title{
Reducing Catheter Acquired Urinary Tract Infections: Mini Report of the State of the Evidence for Indwelling Versus External Urinary Devices
}

\author{
Kelechi TC, Kelechi TJ* and Qanungo S \\ Medical University of South Carolina College of Nursing, USA
}

*Corresponding author: Teresa J Kelechi, Medical University of South Carolina

\section{Review Article}

Volume 1 Issue 6

Received Date: November 13, 2017

Published Date: November 20, 2017 College of Nursing, 99 Jonathan Lucas Street, MSC 160 Charleston SC 29412-1600, United States, Tel: 843-792-4602; Email: kelechtj@musc.edu

\section{Abstract}

Problem: Catheter-associated urinary tract infections (CAUTI) are the most frequent types of hospital acquired infections associated with urinary catheters.

Purpose: The purpose of this mini review was to determine whether external urinary containment devices compared to indwelling containment devices reduce the incidence of CAUTI in hospitalized patients.

Methods: A search of the literature was conducted from years 2012 to present, resulting in extracted data from four studies and one systematic review.

Results: There is no difference between external and indwelling urinary containment devices in the prevalence of CAUTI in hospitalized patients. The same microbial flora is associated with infection in both devices.

Conclusions: There is no recommendation for the use of one type of catheter over the other in preventing CAUTI in patients requiring catheters during hospitalization. Routine catheter care and early removal remain the most important nursing care considerations.

Keywords: CAUTI; Urinary; Evidence; Indwelling; Infections

\section{Introduction}

Hospitalization is a risk factor for several infections that lead to poor health care outcomes. Catheterassociated urinary tract infections (CAUTI) are the most frequent types of hospital acquired infections, and are associated with many negative complications such as pyelonephritis, bacterial endocarditis, and urosepsis [1]. There are an estimated 13,000 deaths a year attributed to CAUTI [1]. CAUTI is defined as an infection occurring in individuals whose urinary tract is currently catheterized or has been catheterized within the previous 48 hours [2]. Several measures have been proposed to reduce the incidence of CAUTI such as limiting the use of indwelling catheters in females and elderly patients due to high morbidity and mortality rates in these populations [3]. Catheter associated urinary tract infection in hospitalized patients can lead to longer lengths of stay, additional treatment for the infection that can result in medication interactions and other side effects, and increased patient discomfort during the stay [4]. Sex differences have been reported in CAUTI with females having higher rates [5]. 


\section{Nursing \& Healthcare International Journal}

However, there is a lack of research to suggest causative factors associated with higher CAUTI rates in females, speculated to be related to the external genitalia harboring more organisms. With the introduction of new external urinary devices for females, there may be differences in the incidence of CAUTI in hospitalized females [5].

Several guidelines suggest indwelling catheters should be used for brief periods during hospitalization, and should be removed quickly to prevent complications $[1,6]$. However, there are patients who need to have catheters in place for longer periods of time. New types of external devices, such as the vacuum assisted for females (e.g., Purewick) or external pouches for men (e.g., Liberty) may reduce this risk. The purpose of this mini review was to examine the literature on the effects of external urinary collection devices on CAUTI in hospitalized patients. The search question was: Do external urinary containment devices compared to indwelling containment devices reduce the incidence of catheter associated urinary tract infections (CAUTI) in hospitalized patients?

\section{Search Strategies}

The literature was searched in PubMed, CINAHL, Virginia Henderson, Google Scholar, and Scopus for the use of urinary containment devices in hospitalized patients, from years 2012 to present. Inclusion criteria included adults, CAUTI, all published in English. Search terms were indwelling catheters, urinary incontinence, external, vacuum, mechanical devices, urinary management systems, catheter associated urinary tract infections, condom catheters, and urinary diversions. Exclusion criteria were pediatric urinary infections, urinary infections not associated with catheter insertion, and treatment for CAUTI. With the assistance of a medical librarian, the search yielded 52 papers, including systematic reviews, clinical trials, clinical guidelines, clinical papers in medicine and nursing, and reviews of the literature. Abstracts were then retrieved and after review for relevance to CAUTI in the hospital setting, 21 articles were retrieved, of which 4 were studies, and 1 was a systematic review, which are included in this paper. An older classic study from 2006 is included as one of the 4 studies as it remains a frequently cited paper (Table 1 ).

\begin{tabular}{|c|c|c|c|c|c|c|c|}
\hline Authors & Purpose & $\begin{array}{l}\text { Design/ } \\
\text { Method }\end{array}$ & $\begin{array}{l}\text { Sample/ } \\
\text { Setting }\end{array}$ & $\begin{array}{c}\text { Major } \\
\text { Variables } \\
\end{array}$ & Study Finding & $\begin{array}{c}\text { Study Strengths \& } \\
\text { Weaknesses }\end{array}$ & $\begin{array}{c}\text { Significance for } \\
\text { Practice }\end{array}$ \\
\hline $\begin{array}{l}\text { Lipp A, Shaw } \\
\text { C, Glavind K } \\
\text { (2014) }\end{array}$ & $\begin{array}{l}\text { Determine } \\
\text { usefulness } \\
\text { of } \\
\text { mechanical } \\
\text { devices in } \\
\text { female } \\
\text { urinary } \\
\text { incontinen } \\
\text { ce. }\end{array}$ & $\begin{array}{c}\text { Trials } \\
\text { identified from } \\
\text { the Cochrane } \\
\text { Register of } \\
\text { Controlled } \\
\text { Trials, and } \\
\text { hand searching } \\
\text { of journals and } \\
\text { conference } \\
\text { proceedings. }\end{array}$ & $\begin{array}{c}\text { All } \\
\text { randomized } \\
\text { or quasi- } \\
\text { randomized } \\
\text { controlled } \\
\text { trials. Total } \\
\text { reviewed } \\
\text { were } 3 \\
\text { studies from } \\
\text { The Cochrane } \\
\text { Central } \\
\text { Register of } \\
\text { Controlled } \\
\text { Trials } \\
\text { (CENTRAL), } \\
\text { MEDLINE, } \\
\text { MEDLINE in } \\
\text { process, } \\
\text { ClinicalTrials. } \\
\text { gov, WHO } \\
\text { ICTRP } \\
\end{array}$ & $\begin{array}{l}\text { Independent } \\
\text { variable: } \\
\text { Management of } \\
\text { adult female } \\
\text { urinary } \\
\text { incontinence } \\
\text { determined by } \\
\text { symptom, sign, } \\
\text { or urodynamic } \\
\text { diagnosis. } \\
\text { Dependent } \\
\text { variables: Self } \\
\text { reported } \\
\text { symptoms, } \\
\text { objective } \\
\text { clinical } \\
\text { measures, } \\
\text { tolerability of } \\
\text { device and side- } \\
\text { effects }\end{array}$ & $\begin{array}{c}\text { There is insufficient } \\
\text { evidence from controlled } \\
\text { trials to determine } \\
\text { whether mechanical } \\
\text { devices should be a } \\
\text { preferred treatment over } \\
\text { other methods such as } \\
\text { indwelling catheters. }\end{array}$ & $\begin{array}{l}\text { Strengths: Self reported } \\
\text { symptoms are included as } \\
\text { well as tolerability, two } \\
\text { factors that have not been } \\
\text { previously reported in the } \\
\text { literature. Limitations: } \\
\text { Study searched too wide of } \\
\text { a spectrum of variables for } \\
\text { the data. Should have } \\
\text { focused more specifically } \\
\text { on certain aspects that } \\
\text { mechanical devices either } \\
\text { improve, worsen, or } \\
\text { remain the same for } \\
\text { females using catheters. }\end{array}$ & $\begin{array}{c}\text { Compiles data } \\
\text { from many studies } \\
\text { into list form } \\
\text { including many } \\
\text { different } \\
\text { mechanical urinary } \\
\text { devices and their } \\
\text { effective statistical } \\
\text { values in patients. }\end{array}$ \\
\hline $\begin{array}{l}\text { Grigoryan L, } \\
\text { Abers MS, } \\
\text { Kizilbash QR, } \\
\text { Petersen NJ, } \\
\text { Trautner BW } \\
\text { (2014) }\end{array}$ & $\begin{array}{l}\text { To } \\
\text { compare } \\
\text { the } \\
\text { microbiolo } \\
\text { gy profile } \\
\text { (number of } \\
\text { organisms } \\
\text { recovered) } \\
\text { from urine } \\
\text { cultures in } \\
\text { patients } \\
\text { with } \\
\end{array}$ & $\begin{array}{l}\text { Cross-sectional } \\
\text { study }\end{array}$ & $\begin{array}{l}308 \text { patients } \\
\text { from } 5 \\
\text { medicine and } \\
5 \text { extended- } \\
\text { care wards of } \\
\text { a VA care } \\
\text { facility with } \\
\text { external } \\
\text { catheters ( } \mathrm{n}= \\
135 \text { ) and } \\
\text { indwelling } \\
\text { catheters ( } \mathrm{n}=\end{array}$ & $\begin{array}{l}\text { Dependent } \\
\text { variable: type of } \\
\text { organisms } \\
\text { Independent } \\
\text { variable: type of } \\
\text { catheter }\end{array}$ & $\begin{array}{l}\text { Both groups had Gram } \\
\text { positive organisms, but } \\
\text { there were no statistically } \\
\text { significant differences } \\
\text { between groups for } \\
\text { Staphylococci }(\mathrm{p}=0.88) \text {, } \\
\text { Enterococci }(\mathrm{p}=0.83) \text { or } \\
\text { Corynebacterium/Lactob } \\
\text { acillus }(\mathrm{p}=0.41) \text { or for } \\
\text { Gram negative } \\
\text { Enterobacteriaceae (p = } \\
0.57) \text {. Statistically }\end{array}$ & $\begin{array}{l}\text { Strengths: Standardized } \\
\text { laboratory approaches to } \\
\text { analyze data so that all } \\
\text { specimens were treated } \\
\text { identically Large sample } \\
\text { size based on a power } \\
\text { analysis Limitations: There } \\
\text { was no standardized } \\
\text { urinary collection process } \\
\text { from an external catheter } \\
\text { so contamination could } \\
\text { have been a problem. The }\end{array}$ & $\begin{array}{l}\text { External catheters, } \\
\text { once thought to } \\
\text { have less risk of } \\
\text { infection present } \\
\text { similar rates of } \\
\text { infection and have } \\
\text { more organisms as } \\
\text { noted on cultures. } \\
\text { Patients with } \\
\text { external devices } \\
\text { require just as } \\
\text { vigilant of care as }\end{array}$ \\
\hline
\end{tabular}




\section{Nursing \& Healthcare International Journal}

\begin{tabular}{|c|c|c|c|c|c|c|c|}
\hline & $\begin{array}{l}\text { external } \\
\text { and } \\
\text { indwelling } \\
\text { catheters }\end{array}$ & & $\begin{array}{l}\text { 173) with } \\
\text { positive urine } \\
\text { cultures } \\
\text { during period } \\
\text { of October } \\
\text { 2010-June } \\
2011 .\end{array}$ & & $\begin{array}{l}\text { significant differences } \\
\text { were noted for Non- } \\
\text { Enterobacteriaceae }(\mathrm{p}= \\
0.004) \text { and Candida }(\mathrm{p}= \\
0.002) \text { for the indwelling } \\
\text { catheters. There were } \\
\text { more organisms noted } \\
\text { overall for external } \\
\text { catheters ( } \mathrm{p}<0.0001) \\
\text { with } 2.3 \text { versus } 1.7 \text { for } \\
\text { indwelling catheters. }\end{array}$ & $\begin{array}{l}\text { researchers were unaware } \\
\text { of the specific types of } \\
\text { external catheters used, } \\
\text { how they were applied and } \\
\text { if patients wore them } \\
\text { continuously or } \\
\text { intermittently There were } \\
\text { no females in the study so } \\
\text { results may not apply to } \\
\text { them. }\end{array}$ & $\begin{array}{l}\text { those with } \\
\text { indwelling } \\
\text { catheters. }\end{array}$ \\
\hline $\begin{array}{c}\text { Saint S, } \\
\text { Kaufman SR, } \\
\text { Rogers MA, } \\
\text { Baker PD, } \\
\text { Ossenkop, K, } \\
\text { Lipsky A } \\
\text { (2006) }\end{array}$ & $\begin{array}{c}\text { To } \\
\text { compare } \\
\text { condom } \\
\text { and } \\
\text { indwelling } \\
\text { urinary } \\
\text { catheters } \\
\text { in terms of } \\
\text { infection } \\
\text { risk and } \\
\text { patient } \\
\text { satisfactio } \\
n\end{array}$ & $\begin{array}{l}\text { Prospective, } \\
\text { randomized, } \\
\text { unblinded, } \\
\text { controlled trial } \\
\text { conducted } \\
\text { over a 4-year } \\
\text { period }\end{array}$ & $\begin{array}{c}75 \\
\text { hospitalized } \\
\text { men aged } 40 \\
\text { and older } \\
\text { receiving an } \\
\text { indwelling } \\
\text { catheter (n = } \\
41 \text { ) and } \\
\text { condom } \\
\text { catheter ( } \mathrm{n}= \\
\text { 34) in an } \\
\text { academically } \\
\text { affiliated } \\
\text { Veterans } \\
\text { Affairs } \\
\text { Medical } \\
\text { Center }\end{array}$ & $\begin{array}{l}\text { Dependent } \\
\text { variable: } \\
\text { incidence of } \\
\text { adverse } \\
\text { outcomes } \\
\text { (bacteriuria, } \\
\text { symptomatic } \\
\text { urinary tract } \\
\text { [UTI] infection, } \\
\text { death) and } \\
\text { patient device- } \\
\text { related } \\
\text { satisfaction } \\
\text { Independent } \\
\text { variables: } \\
\text { condom versus } \\
\text { indwelling } \\
\text { urinary } \\
\text { catheters }\end{array}$ & $\begin{array}{c}\text { The risk of bacteriuria, } \\
\text { symptomatic UTI, or } \\
\text { death was twice as high in } \\
\text { patients with an } \\
\text { indwelling catheter but } \\
\text { these findings were not } \\
\text { statistically significant. } \\
\text { For bacteriuria }(\mathrm{p}=0.11) \text {, } \\
\text { for UTI }(\mathrm{p}=0.07) \text { and for } \\
\text { death }(\mathrm{p}=0.09) \text { Patients } \\
\text { reported condom } \\
\text { catheters were more } \\
\text { comfortable }(\mathrm{p}=0.02) \\
\text { and less painful }(\mathrm{p}=0.02) \\
\text { than indwelling catheters. }\end{array}$ & $\begin{array}{l}\text { Strengths: Good study } \\
\text { design to randomize } \\
\text { patients to the type of } \\
\text { catheter Asking patients } \\
\text { about their comfort } \\
\text { important to improve } \\
\text { acceptance of the catheter } \\
\text { Limitations: Relatively } \\
\text { small sample of patients } \\
\text { were eligible over the } \\
\text { study period due to } \\
\text { patients refusing } \\
\text { participation and many } \\
\text { already had an infection at } \\
\text { the time of enrollment. The } \\
\text { study was conducted at } \\
\text { one site thus findings may } \\
\text { not be appropriate for } \\
\text { other people with these } \\
\text { types of catheters. }\end{array}$ & $\begin{array}{l}\text { Use of condom } \\
\text { catheter is less } \\
\text { likely to be } \\
\text { associated with } \\
\text { bacteruria and } \\
\text { symptomatic } \\
\text { urinary tract } \\
\text { infection, or death. } \\
\text { There was higher } \\
\text { satisfaction with } \\
\text { the condom } \\
\text { catheter. Based on } \\
\text { these findings, } \\
\text { condom catheter } \\
\text { use should be } \\
\text { considered over } \\
\text { indwelling } \\
\text { catheters, but } \\
\text { more recent } \\
\text { findings contradict } \\
\text { the risk for } \\
\text { infection, as noted } \\
\text { in the Grigoryan } \\
\text { study. }\end{array}$ \\
\hline $\begin{array}{c}\text { Pickard R, } \\
\text { Lam T, } \\
\text { MacLannanG, } \\
\text { Starr K, } \\
\text { Kilonzo M, } \\
\text { McPherson G, } \\
\text { et al. (2012) }\end{array}$ & $\begin{array}{l}\text { To } \\
\text { determine } \\
\text { if three } \\
\text { antimicrob } \\
\text { ial } \\
\text { catheters } \\
\text { reduce the } \\
\text { rate of } \\
\text { symptomat } \\
\text { ic urinary } \\
\text { tract } \\
\text { infection } \\
\text { (UTI) } \\
\text { during } \\
\text { short-term } \\
\text { hospital } \\
\text { use and is } \\
\text { their use } \\
\text { cost- } \\
\text { effective. }\end{array}$ & $\begin{array}{l}\text { Pragmatic } \\
\text { multicenter } \\
\text { randomized } \\
\text { trial }\end{array}$ & $\begin{array}{c}6394 \\
\text { hospitalized } \\
\text { participants } \\
\text { randomized } \\
\text { to receive } \\
\text { one of three } \\
\text { catheters } \\
\text { between } 1 \\
\text { and } 14 \text { days } \\
\text { of their care } \\
\text { after elective } \\
\text { surgery }\end{array}$ & $\begin{array}{l}\text { Dependent } \\
\text { variable: } \\
\text { incidence of UTI } \\
\text { at any time up } \\
\text { to } 6 \text { weeks } \\
\text { Independent } \\
\text { variables: } \\
\text { nitrofurazone } \\
\text { impregnated } \\
\text { silicone catheter } \\
\text { compared with } \\
\text { standard PTFE- } \\
\text { coated latex } \\
\text { catheter; and } \\
\text { silver alloy- } \\
\text { coated hydrogel } \\
\text { latex catheter } \\
\text { compared with } \\
\text { standard PTFE- } \\
\text { coated latex } \\
\text { catheter. }\end{array}$ & $\begin{array}{l}\text { The rate of symptomatic } \\
\text { UTI within } 6 \text { weeks of } \\
\text { catheter use was } 10.6 \% \text { in } \\
\text { the nitrofurazone group } \\
\text { (n = 2153); } 12.5 \% \text { in the } \\
\text { silver alloy group ( } \mathrm{n}= \\
\text { 2097); and } 12.6 \% \text { in the } \\
\text { PTFE group ( } \mathrm{n}=2144) \text {. } \\
\text { The effect size \{odds ratio } \\
\text { (OR) [97.5\% confidence } \\
\text { interval (CI)]\} was } 0.82 \\
\text { (97.5\% CI } 0.66 \text { to } 1.01) \\
\text { for nitrofurazone ( } \mathrm{p}= \\
0.037 \text { ) and } 0.99 \text { (97.5\% CI } \\
0.81 \text { to } 1.22 \text { ) for silver } \\
\text { alloy (p = } 0.92 \text { ) catheters. } \\
\text { The nitrofurazone } \\
\text { catheters were more } \\
\text { likely to cause discomfort } \\
\text { during use and on } \\
\text { removal. Costs: } \\
\text { nitrofurazone } \\
\text { impregnated catheters } \\
\text { would be, on average, the } \\
\text { least costly and most } \\
\text { effective option. }\end{array}$ & $\begin{array}{l}\text { Strengths: Very large } \\
\text { sample size in each group } \\
\text { to determine differences } \\
\text { among the three different } \\
\text { catheters The methods for } \\
\text { using the catheters were } \\
\text { the same (the insertion of } \\
\text { the catheters was done by } \\
\text { study personnel using the } \\
\text { same techniques) } \\
\text { Limitations: Latex } \\
\text { catheters are no longer in } \\
\text { use in the U.S. but these } \\
\text { catheters had higher } \\
\text { infection rates and were } \\
\text { the most expensive. The } \\
\text { protocols at all of the 20+ } \\
\text { institutions included in the } \\
\text { study were not clearly } \\
\text { stated so it was difficult to } \\
\text { determine if there was a } \\
\text { standard protocol followed } \\
\text { and if not, infection could } \\
\text { have been attributed to } \\
\text { procedural factors. }\end{array}$ & $\begin{array}{l}\text { While the } \\
\text { nitrofurazone } \\
\text { group had lower } \\
\text { rates of infection } \\
\text { and those } \\
\text { catheters were } \\
\text { cheaper to use, } \\
\text { they were more } \\
\text { likely to cause } \\
\text { discomfort. This is } \\
\text { a problem to } \\
\text { determine whether } \\
\text { lower infection } \\
\text { rates are more } \\
\text { important than a } \\
\text { catheter that is } \\
\text { more conformable } \\
\text { for patients. Newer } \\
\text { catheters are now } \\
\text { on the market but } \\
\text { there are no } \\
\text { clinical trials to } \\
\text { determine whether } \\
\text { they are better } \\
\text { than those } \\
\text { currently in use in } \\
\text { terms of infection } \\
\text { and patient } \\
\text { satisfaction. }\end{array}$ \\
\hline
\end{tabular}




\section{Nursing \& Healthcare International Journal}

\begin{tabular}{|c|c|c|c|c|c|c|c|}
\hline $\begin{array}{l}\text { Medina Polo J, } \\
\text { Guerrero } \\
\text { Ramos F, } \\
\text { Perez Cadavid } \\
\text { S, Arrebola } \\
\text { Pajares A, } \\
\text { Sopena Sutil R, } \\
\text { Benitez Sala R, } \\
\text { Tejido } \\
\text { Sanchez A } \\
\text { (2015) }\end{array}$ & $\begin{array}{c}\text { To } \\
\text { determine } \\
\text { risk factors } \\
\text { and } \\
\text { microbial } \\
\text { characteris } \\
\text { tics of } \\
\text { communit } \\
y^{-} \\
\text {associated } \\
\text { UTIs } \\
\text { requiring } \\
\text { hospitaliza } \\
\text { tion. }\end{array}$ & $\begin{array}{c}\text { Prospective } \\
\text { observational } \\
\text { study. }\end{array}$ & $\begin{array}{c}475 \\
\text { hospitalized } \\
\text { patients with } \\
\text { community } \\
\text { associated } \\
\text { UTIs }\end{array}$ & $\begin{array}{l}\text { Dependent: } \\
\text { Community } \\
\text { associated UTIs } \\
\text { Independent: } \\
\text { Gender, age, } \\
\text { Indwelling } \\
\text { catheter, and } \\
\text { previous UTI. }\end{array}$ & $\begin{array}{l}\text { Mean age } 56.2+-19.85 \\
\text { years. } 52.1 \% \text { patients } \\
\text { were woman, } 19.7 \% \text { had } \\
\text { urinary indwelling } \\
\text { catheter, and } 11.4 \% \text { have } \\
\text { had a previous UTI. The } \\
\text { most frequently isolated } \\
\text { pathogens were } \\
\text { Escherichia coli (60.6\%), } \\
\text { Klebsiella (9.2\%), } \\
\text { Enterococcus (8.4\%), and } \\
\text { Pseudomonas }(7.2 \%) \text {. } \\
\text { Most frequent isolated in } \\
\text { patients with pervious } \\
\text { UTI and a urinary } \\
\text { catheter was } \\
\text { Enterococcus. }\end{array}$ & $\begin{array}{l}\text { Strengths: uses a large } \\
\text { controlled group yielding } \\
\text { precise microbiological } \\
\text { data for infections. } \\
\text { Limitations: The study } \\
\text { does not specify the } \\
\text { percentage of men and } \\
\text { woman separately who } \\
\text { had previous UTIs and } \\
\text { indwelling urinary } \\
\text { catheters. }\end{array}$ & $\begin{array}{c}\text { Gaining specificity } \\
\text { on percentages of } \\
\text { the initial causes of } \\
\text { CAUTI is important } \\
\text { to establish } \\
\text { methods of } \\
\text { prevention. } \\
\text { Specificity in the } \\
\text { microbiology of the } \\
\text { infections also } \\
\text { gives data upon } \\
\text { which to } \\
\text { determine the } \\
\text { types of bacteria } \\
\text { that cause } \\
\text { infections and } \\
\text { those that are } \\
\text { antibiotic resistant. }\end{array}$ \\
\hline
\end{tabular}

Table 1: Literature Table.

\section{Results}

Data from multiple sources (Table 1) including a large literature review of mechanical devices for the management of urinary incontinence in females [5], findings from a randomized study of indwelling versus external urinary catheters on the incidence CAUTI [7], and results from laboratory studies of both indwelling versus external catheters on the types of organisms present in the urine [8], suggest the best approach to the management of urinary incontinence and prevention of CAUTI remains elusive. There is no recommendation for the use of one type of catheter over the other in preventing infection in patients requiring catheters during hospitalization. Similar organisms are present in both indwelling and external devices, and there is conflicting data on whether external catheters are associated with fewer infections. An older study conducted by Saint, et al. in 2006 reported fewer catheter associated infections; however, a more recent paper by Grigorva, et al. (2015) demonstrated no differences. Indwelling catheters have been associated with discomfort but there are limited data on which ones are more comfortable and tolerable. There were no studies on a newer vacuum assisted device for females or pouches for males that could be located. Thus it is unclear whether these types of devices are associated with fewer infections and are more acceptable to patients.

\section{Discussion}

It is well established that the main causative organisms for infections are those from the perineal flora that invade the urinary system. Researchers have studied the types of materials used in indwelling catheters and found that silicone catheters containing ntirofurazone compared to latex catheters resulted in lower rates of CAUTI, however the nitrofurazone-containing catheters were reported to cause more discomfort [9]. Discomfort is not well studied in relation to the use of indwelling or external catheters, however in one study by Saint, et al. [7], male patients preferred condom catheters (external devices) over indwelling catheters. A downfall of this study is it is older, with more recent studies unable to be located to corroborate this finding. A limitation of the study by Saint was that it was conducted only in male patients. In fact, most of the studies of external devices were conducted in males as few external options exist for females. While new types of external devices are being used in females, there is a lack of research to determine if these devices are better than indwelling catheters on comfort and preventing CAUTI. Finally, some studies suggest that having had a previous CAUTI places one at higher risk of developing a recurrent CAUTI. However, findings from a study by Medina-Polo, et al. (2015) [10] suggest that a lower number of individuals had recurrent infections with catheter use, suggesting a previous infection was not predictive of another CAUTI. Current evidence, while limited, is conflicting regarding whether indwelling catheters place individuals at higher risk for CAUTI. The evidence is in support of short term use of both types of catheters, thus there is no one type considered better than the other. This is particularly so for females; for males, external catheter use may be preferred but there is weak evidence in support of external catheters as a means to reduce CAUTI.

\section{Implications for Practice}

Care of hospitalized patients requires vigilant assessment for infection, particularly CAUTI. Based on the 


\section{Nursing \& Healthcare International Journal}

evidence presented in this mini review, short term use of catheters in patients in the hospital setting remains a strong recommendation to prevent CAUTI. In the hospital setting, similar organisms are common in both indwelling catheters and external containment devices, urinary tract infections increase with longer use with both types of catheters, and external devices may be more comfortable for males, but this has not been studied in females. Keeping the perineal area clean remains a critical nursing consideration as the organisms that lead to infection are mostly from the perianal area. Assessing patients for pain or discomfort and offering a choice, if possible, of the type of catheter are additional recommendations. Regular inspection of the urinary meatus and routine cleansing of the meatus during bathing or showering without the use of antiseptics remains two of the most crucial nursing considerations [11]. Unfortunately, there is limited information about new external urinary collection devices for females to suggest efficacy over indwelling catheters for short term use to prevent CAUTI. Until then, caution should be used when utilizing these devices for both females and males as there are very limited trials to suggest if they are better than indwelling catheters.

\section{References}

1. Gray M, Skinner C, Kaler W (2016) External collection devices as an alternative to the indwelling urinary catheter: Evidence-based review and expert clinical panel deliberations. J Wound Ostomy Continence Nurs 43(3): 301-307.

2. Hooten TM, Bradley SF, Cardenas DD, Colgan R, Geerlings SE, et al. (2010) Diagnosis, prevention, and treatment of catheter-associated urinary tract infection in adults: 2009 International Clinical Practice Guidelines from the Infectious Diseases Society of American. Clinical Infectious Diseases 50(5): 625-663.

3. Theobald CN, Resnick MJ, Spain T, Dittus RS, Roumie CL (2017) A multi-faced quality improvement strategy reduces the risk of catheter-associated urinary tract infection. Int J Qual Health Care 29(4): 564-570.
4. Metersky ML, Eldridge N, Wang Y, Mortensen EM, Meddings J (2017) National trends in the frequency of bladder catheterization and physician-diagnosed catheter-associated urinary tract infections: Results from the Medicare Patient Safety Monitoring System. Am J Infect Control 45(8): 901-904.

5. Lipp A, Shaw C, Glavind K (2014) Mechanical devices for urinary incontinence in women. Cochrane Database Systematic Reviews (12).

6. Clayton JL (2017) Indwelling urinary catheters: A pathway to health care-associated infections. AORN J 105(5): 446-452.

7. Saint S, Kaufman SR, Rogers MA, Baker PD, Ossenkop $\mathrm{K}$, et al. (2006) Condom versus indwelling urinary catheters: a randomized trial. J Am Geriatr Soc 54(7): 1055-1061.

8. Grigoryan L, Abers MS, Kizilbash QF, Petersen NJ, Trautner BW (2014) A comparison of the microbiologic profile of indwelling versus external urinary catheters. Am J Infect Control 42(6): 682-684.

9. Pickard R, Lam T, Maclennan G, Starr K, Kilonzo M, et al. (2012) Types of urethral catheter for reducing symptomatic urinary tract infections in hospitalized adults requiring short-term catheterisation: multicentre randomised controlled trial and economic evaluation of antimicrobial- and antisepticimpregnated urethral catheters (the CATHETER trial). Health Technol Assess 16(47): 1-197.

10. Medina Polo J, Guerrero Ramos F, Perez Cadavid S, Arrebola Pajares A, Sopena Sutil R, et al. (2015) Community-associated urinary infections requiring hospitalization: risk factors, microbiological characteristics and patterns of antibiotic resistance. Actas Urologicas Espanolas 39(2): 104-111.

11. Gould CV, Umscheid CA, Agarwal RK, Kuntz G, Pegues DA, \& the Healthcare Infection Control Practices Advisory Committee (HICPAC) (2017) Guideline for Prevention of Catheter-Associated Urinary Tract Infections 2009. 